\title{
The Empress of the French. ICONOGRAPHY OF JOSÉPHINE DE BEAUHARNAIS
}

\author{
Teresa Llácer Viel
}

Universitat Jaume I

Resumen: El 2 de diciembre de 1804, Josefina de Beauharnais (Martinica, 23 de junio de 1763 - Rueil-Malmaison, 29 de mayo de 1814), fue coronada como emperatriz de los franceses en la catedral de Notre-Dame. Su esposo, Napoleón Bonaparte (Ajaccio, 15 de agosto de 1769 - Santa Elena, 5 de mayo de 1821), colocaba sobre su cabeza la réplica de la corona de Carlomagno ante la mirada del papa Pío VII (1742-1823). La que fuera vizcondesa de Beauharnais, de nacimiento criolla, llevaría el manto imperial durante seis años hasta la formalización de su divorcio de Bonaparte el 10 de enero de 1810.

Palabras clave: iconografía del poder, Josefina de Beauharnais, Napoleón Bonaparte, Primer Imperio francés.

Abstract: On the second of December 1084, Joséphine de Beauharnais (née Tascher de la Pagerie in Martinica; 23 June 1763 - 29 May 1814 in Rueil-Mailmaison) was crowned as Empress of the French in the Cathedral of Notre-Dame. Her husband, Napoleon Bonaparte (Ajaccio, 15 August 1769 - Saint Ellen, 5 May 1821) placed on her head the replica of the crown of Charlemagne before Pope Pius VII (1742-1823). The former vizcountess of Beauharnais, born a creole, would be wearing the imperial cape for six years until her official divorce from Napoleon on 10 January 1810.

Keywords: Iconography of power, Joséphine de Beauharnais, Napoleon Bonaparte, First French Empire. 


\section{THE IMPERIAL EMBLEMS IN THE NAPOLEONIC PORTRAIT}

Toséphine de Beauharnais, widow of Alexandre de Beauharnais (1760-1794), met young Napoleon at a time when she often visited Madame Tallien's house, in La Chaumière, the residence of Paul François Jean Nicolas, viscount of Barras and the neo-Greek pavillion on Chanteriene Street. At that time, barely could the countess imagine her future on the throne of France next to the person who, according to her own words, she once described as «a clumsy rude Corsican». ${ }^{1}$ After a period of dates and meetings they found it convenient to marry - Bonaparte first approached the window because he thought she was rich, ${ }^{2}$ and Joséphine accepted since she thought that the marriage could benefit her children. ${ }^{3}$ But, despite the apparent shallowness of the marital cohabitation, the general soon developed a real passion for her.

Je me réveille plein de toi. Ton portrais et le souvenir de l'énivrante soirée d'hiers n'ont point laissé de repos à mes sens. [...] En attendant, mio dolce amor, reçois un millier de baisé; mais ne m'en donne pas, car il brûle mon sang. ${ }^{4}$

The couple got engaged in January 1796 and was civilly married on 9 March of that year; soon they went through a vertiginous period of military campaigns, political changes and marital conflicts: The campaigns in Italy (1796-1797), Egipt and Syria (1798-1801); the marital infidelity on both parties, ${ }^{5}$ the threatens of divorce and the coup on 18 brumaire, the stage at the Consulate and the foundation of the Empire with the proclamation of Bonaparte as Emperor.

Although it is true that there is artistic production around the figure of the general and his wife before the consolidation of the Empire, it is also true that the portraits and the topics of those of Joséphine, which seems reasonable, since at the time Bonaparte was a rising political and military figure ${ }^{6}$ whereas Joséphine remained in the background.?

With the foundation of the empire the consort of the ruler was facing a critical period of her personal image as she no longer was the wife of the

\footnotetext{
1. Christopher Hibbert: Napoleon, His Wives and Women, HarperCollins, New York, 2002, pp. 65-66. 2. In a confession to count Bertrain he stated: «I really loved Joséphine, but I did not respect her. She had the most beautiful little pussy in the world... I married her only because I thought her rich. She said she was, but it was not true». Ibidem, p. 67.

3. Ibidem, p. 67.

4. Chanceaux, le 24 ventôse, en route pour l'armée d'Italie.

5. It is particularly remarkable the affair Joséphine had with hussar lieutenant Hippolyte Charles (17721837).

6. Napoleon crossing the Alps (Jacques-Louis David, 1800-1801); Bonaparte on the Bridge of Arcole (Antoine-Jean Gros, c. 1801); Battle of Marengo (Louis-François Lejeune, 1802); Napoleon as First Consul (François Gérard, 1803).

7. Portrait of Madame Bonaparte (François Gérard, 1801); Portrait of Joséphine in Malmaison (JeanBaptiste Isabey, c. 1800); Portrait of Joséphine de Beauharnais (Pierre Paul Prud'hon, 1800).
} 
Consul but the Empress of the French. The portraits were multiplied, however, and despite the enormous production of images that shaped her iconography, this article intends to focus on those works in which Madame Bonaparte is portrayed with a strong symbolic presence of the corpus of the Napoleonic system. Through the portraits of Joséphine in which the elements of propaganda strategy become manifest, we will see how the person of Joséphine herself became a vehicle of imperial propaganda: a female reference should provide a solid image of the consort of the emperor a reflection of the very machinery of the imperial dignity and an example of the optimal structure of the ruling family. The fact that the figure of the emperor is palpable in some of the portraits of Madame Bonaparte was obtained by using a visual language that the Napoleonic publicity commissioned configure and set by assimilating inherited symbols of classical antiquity and monitoring systems of representation of the Old Regime.

Napoleon Bonaparte had, undoubtedly, a passion for history, art and classical Roman culture. The admiration that the classical past inspired him, led him to order the artistic plundering his troops held in the Italian states, the material with which they supplied the National Museum in Paris and with which then general managed to set up a popularized plan that which equate the Roman Ceasars. ${ }^{8}$

Also, as indicated by Víctor Mínguez and Inmaculada Rodríguez, there were two main reasons why Napoleon decided to emulate the great classics: the parallelism of the French political and social situation of the moment with the historical past of Rome as republics of military hegemony among which a general stood up and who was promoted to a top leading position and proclaimed himself emperor and «the symbolic codes of the artistic representations of European kings of the Old Regime, based on doublefold dynastic and divine legitimacy, the iconographic construction of Napoleon». It is because of this that he starts a campaign in order to establish his legitimacy by building bridges with key figures in Western history such as Alexander or Charlemagne, ${ }^{9}$ and identifying himself more specifically with the Roman Caesars upon being crowned as emperor, being specifically relevant the figure of Julius Caesar.

With the advent of the nineteenth century Herculaneum and Pompeii were discovered bringing out their archaeological remains. That is why the presence of classical models in the early nineteenth century and the importance of the classic imperial Roman portrait in Napoleonic iconography were logical consequences which arose from such findings. ${ }^{10}$ To finish up their propaganda

8. Víctor Mínguez; InMaculada Rodríguez: Napoleón y el espejo de la Antigüedad, Universitat de València. Servei de Publicacions, Valencia, 2014, p. 25.

9. Víctor Mínguez: «La iconografía del poder. Fernando VII y José I. Apoteosis y escarnio en la disputa del trono español». En: A. Ramos Santana; A. Romero Ferrer (eds.): 1808-1812: Los emblemas de la libertad, Universidad de Cádiz, Cádiz, 2009a, pp. 161-189.

10. Mínguez, Rodríguez, Napoleón y el espejo..., pp. 20-26. 
plan, the artists working for the emperor used to keep in mind the aesthetics of the Roman Empire: architecture, statuary, gems and coins were the main sources of inspiration of the artists so as to apprehend the caesarean system of representation. ${ }^{11}$ Moreover, in order to achieve the expansion of the Napoleonic corpus, the emperor resorted to a number of artists like JacquesLouis David (1748-1825), Antoine-Jean Gros (1771-1835) and Jean-Auguste Dominique Ingres (1780-1867). ${ }^{12}$

\subsection{The Eagles}

The bird of prey has always been a bearer of the imperial image, which is why many superpowers have hoisted such remarkable animal on their shields. The reason that led the rulers to choose it was the tradition of the model that the Roman Empire established taking the eagle as a symbol of imperial dignity. This iconography was transmitted through the artworks that became known during the Renaissance, which served as a pretext to overcome the medieval archetypes and seat the new patterns. ${ }^{13}$

Upon being crowned Emperor of the French, Napoleon addresses the question of the emblems on 23 Prairial (June 12) during a session in the Council of State. Choosing a new symbolic corpus while it was necessary to establish a distance with the old regime of the Bourbons, it was also essential to take advantage of motifs inspired by ancient classical symbols in order to legitimize their recent coronation.

The selection is complex: Emmanuel Cretet proposes the eagle, lion and elephant while Jean-Jacques Régis de Cambacérès has a preference for bees, arguing that France is a state with a leader and thus acts with the very hierarchy of a honeycomb. Philippe-Paul chooses the lion, omnipresent animal in the iconography of power, and Jean-Charles-Joseph Laumond opts for the elephant. Gérard Christophe Michel Duroc consider the ash tree and Charles-François Lebrun prefers the lily to be the emblem of France and not of the Bourbon royal family. Finally, on 21 Messidor Year XII (10 July 1804), the emperor imposed the eagle on the decree that established his seal and arms. ${ }^{14}$

11. «Ceremonies such as the triumph or the apotheosis were linked to the imperial myth and allegory, astrology and mythology propagandistic languages were used in the construction of cesarean iconographic image. Rites and symbols that would be recovered centuries later during the Renaissance, later reused by absolute monarchs, and finally used by Napoleon». MínguEz, Rodríguez, Napoleón y el espejo..., pp. 2627. For the image of power in classical Greece and Rome see Yves Perrin; Thierry Petit: Iconographie imperial, iconography royale, iconography dans le monde des elite Greco-Roman, Université de SaintEtienne, Saint Etienne, 2004; Jane Fejfer, Roman Portraits in Context, Walter de Gruyter, Berlin, 2008, and Winkes, R. (ed.): Portraits and Propaganda: Faces of Rome, Brown University, Providence, 1989.

12. Mínguez, Rodríguez, Napoleón y el espejo..., pp. 31 y 67.

13. Ibidem, pp. 30 and 41.

14. Philippe Lamarque: Armorial du Premier Empire, Gui, Paris, 2008. 


\subsection{The Sun}

At the origin of civilizations the sun was worshiped as an image of divinity and subsequent assimilation between the divine and royal turned the religious symbolism of the Sun into political symbolism. This practice made the Sun the very image of power ${ }^{15}$ and persisted in the worship of Olympian and Roman gods. ${ }^{16}$

Despite the great number of topics that Napoleon absorbed from the Roman imperial iconography, the solar image was paradoxically not as remarkable as others. However, the general was aware of the symbolic power that the solar metaphor had on the visual construction of absolutist monarchies during the Ancient Regime, particularly to the French royal house. Obsessed with legitimizing his rising, Bonaparte knew he should maintain a balance between identification with the symbols of the old monarchy without renouncing to their revolutionary commitments. ${ }^{17}$

\subsection{The bees}

In pursuit of an imaginary self, Napoleon also foresaw the election of a personal emblem that would link with the past and had perpetuity in the future. ${ }^{18} \mathrm{He}$ chose the bee because of the link the insect held with the French Capetian kings, monarchs since $987 .{ }^{19}$ The reason was that small golden bees had been found in the tomb of Childeric I in 1653 when the sovereign burial was discovered in Tournai. ${ }^{20}$

The insect accompanied Napoleon since he ascended the throne. ${ }^{21}$ Carpets with bees ornated the throne room of the Tuileries; in satin banners of the Russian campaign shone golden bees; when he was deported to the island of

15. See Víctor Mínguez: Los reyes solares: iconografía astral de la monarquía hispánica, Universitat Jaume I. Servei de publicacions, Castellón de la Plana, 2001.

16. See Mínguez, Los reyes solares, and Mínguez, Rodríguez, Napoleón y el espejo..., p. 91.

17. The Sun King in the Napoleonic myth «was present in African and Asian deserts in the campaign of Egypt and Syria; was a key element in the image of the power of the pharaohs, the ancient civilization that expedition led by Bonaparte in Paris and throughout Europe; and since the battle of Austerlitz ». Mínguez, RODRÍGUEZ, Napoleón y el espejo..., p.107.

18. See Leon Bloy: El alma de Napoleón, S. L. Fondo de Cultura Económica de España, Madrid, 2006, and Vicent Cronin: Napoleón Bonaparte: una biografía intima, S. A. Ediciones B, Barcelona, 2003.

19. Napoleon entrusted Vivant Denon the design of the emblem that would represent the Empire and, according to Paul Strathern, Denon was inspired by one of the Egyptian hieroglyphics that he studied in the Egyptian expedition in which he accompanied the general. The author claims that the intention of Denon was to symbolize industry and sweetness, but with the power to sting. Paul Strathern: Napoleón en Egipto, Planeta, Barcelona, 2009, p. 512.

20. M. L'Aвве́ Соснет: Le tombeau de Childéric $1^{\text {er }}$, roi des Francs, restitué à l'aide de l'archéologie et des découvertes récents faites en France, en Belgique, en Suisse, en Allemagne et Angleterre, Paris, 1859.

21. Philippe Lamarque: Armorial du Premier Empire; for a more educational source see «History of the Two Empires: The Symbols of Empire» en la web Fondation Napoléon http://www.napoleon.org/en/ home.asp [Consulted on 9-1-2015]. 
Elba, ${ }^{22}$ in possession of the title of emperor and ruler of the island, he designed a drawing on the old flag of the Medicis, with three golden and scarlet bees.

This insect has a long tradition as a symbol and it is highly likely that the Capetian took the symbolism of immortality and the hierarchical aspect of a honeycomb structured around a queen bee. However, if there is a slogan among all Bonaparte might have assimilated it was that of QUA SE CUNQUE, ${ }^{23}$ created by abbot Emanuele Tesauro in honor of the authority with which Phillip III led his armies like a queen bee surrounded by worker bees. ${ }^{24}$ Yet it should not be forgotten that this insect also served as a reminder of immortality. The ancients believed that bees were born of a dead calf: ${ }^{25}$ ALIENO E FUNERE VITAM, ${ }^{26}$ which stated the value of the passion of the Redeemer, who found eternal life after death: «He was delivered over to death to give life to his people». ${ }^{27}$

\subsection{The crown}

The culminating moment that definitely determined the imperial iconography of Joséphine was the coronation in the presence of Pope Pius VII held on December 2, 1804, in the cathedral of Notre-Dame.

The representation of the imperial image through the coronation by the Pope, chief representative of God among men, survived the French Revolution in orders to reach Le Sacre of Napoleon I in a ceremonial perfomance, following and combining the Roman, Carolingian, Byzantine and Germanic tradition, but also innovative elements. ${ }^{28}$ In order to emphasize his high political status, Bonaparte created an entire corpus of images that sought to legitimize his ascent to the throne of France, ${ }^{29}$ and the imperial crown was the mark of God's sovereign choice. With the blessing of the crowns and by means of the sacramental prayers, both the Pope and the clergy reminded Napoleon of his mortality and his duties as an emperor. ${ }^{30}$

22. Frank MCLynn: Napoleon, Pimlico, Londres, 1998, pp. 593-594

23. «Wherever him».

24. Filippo Picinelli: El mundo simbólico: serpientes y animales venenosos, los insectos, El Colegio de Michoacán y D.R. Consejo Nacional de Ciencias y Tecnología, México, 1999, cap. Los insectos I, La abeja como la autoridad regia, p. 214

25. As indicated by Aelianus in a History of animals; Virgil Georgics; Porfirio in Cave of the Nymphs; Nicandro in Ther or Casiano Baso in Geoponica or extracts from agriculture.

26. «From others' funeral comes life»,

27. Filippo PiCinelli, El mundo simbólico, cap. Los insectos I, La abeja como Cristo muerto, p. 209.

28. See Marc Bloch: Los reyes taumaturgos, Fondo de Cultura Económica, México. 1988; E. Eichmann, Die Kaiser-Krönung im Abendland, Würzburg, 1942; R. Elze, Die Ordines für die Weihe und Krönung des Kaisers und Kaiserin, Hannover, 1960; MíNguez; RodríGuez, Napoleón y el espejo..., pp. 135136; B. Wilkinson: The Coronation in History, 1953; Reginald Maxwell Wooley: Coronation rites, Cambridge: University Press, Cambridge, 1915; János M. BAK (ed.): Coronations. Medieval and Early Modern Monarchic Ritual, Berkeley, Los Ángeles, Oxford: University of California Press, 1990.

29. Mínguez; Rodríguez, Napoleón y el espejo..., p. 153.

30. «Omnipotens sempiterne Deus, qui terrenos reges et imperatores ad exemplum Davidis dilectitui, Salomonais et Joae, diadematibus insigniri voluisti, ut dum régnant in terris gemmarum fulgore et 
Despite everything written at the time of the ceremony, it must be emphasized that the Crown of Charlemagne was not an ancient but a modern crafted object. Only some enamels and cameos came from a fifteenth century reliquary. The design was inspired by two engravings of the eighteenth century, exhibited in Monuments de la monarchie française (1734), by Bernard de Montfaucon. What the propagandist strategy tried to achieve with this replica was to turn the jewel into a sign that marked the renewed link with the Carolingian Empire.

\subsection{The laurel}

The laurel wreath came from classical antiquity being a distinctive sign of victory. In fact, already in Greece and Rome it was put on the head of poets, soldiers and athletes as top prize. Pliny wrote about men who managed to produce fire by rubbing wood, among which laurel and ivy ${ }^{31}$ were highly rated. That is why some of the heraldists would made artworks with crossed branches of laurel with the significance of power obtained by the pact between two powers, so it became the military emblem of Burgundy, and an endeavour of Philip II of Spain. ${ }^{32}$

According to Greek mythology, Apollo, victim of a crush caused by an arrow from Eros, fell madly in love with the nymph Daphne. The Sun Good chased the young nymph who, wishing to preserve her virginity, begged her father for help who finally saved her by turning her into a laurel tree. Apollo later made the laurel his sacred tree. ${ }^{33}$ The Victoria is commonly represented with a laurel wreath according to the custom of the Pythian Games at Delphi consecrated to the same god.$^{34}$ In the same way the god represents victory, the laurel assimilates the virtues of him. ${ }^{35}$ That is why the laurea became the honor

ornamentorum splendore vivam tuae majestatis exibeant imaginem, effunde, quaesumus, super cronas istas benedictionem tuam, ut qui eas gestaverint, virtutum nitore fulgeant». JEAN Tulard, Le Sacre de l'empereur Napoléon: Histoire et légende, Fayard, Paris, 2004, p. 48.

31. Pliny, Natural History XVI, 40. Other sources are SeneCA, Naturales Quaestiones II, 22; LuCretius, De rerum natura $\mathrm{V}, 1098 \mathrm{ff}$

32. Claude Paradin, Symbola heroica M. Claudii Paradini, Belliiocensis canonici, et D. Gabrielis Symeonis: multo quam antea, fidelius de Gallica lingua in Latinam conversa, Antverpiae: Christophori Plantini, 1567, p. 49r. JoAChim CAmerarius, Symbolorum et emblematum ex re Herbaria desumptorum centuria una collecta a Iochimo Camerario medico Norimberg. In quib' rariores Stirpium proprietates historiae ac Sententiae memorabiles non paucae breviter exponuntur, Impensis Johannis Hofmanni \& Huberti Camoxij, Norimbergae, 1590, i, emb. xxxini, p. 66. Silvester Petrasancta, De Symbolis Heroicis, Plantiniana Balthasaris Moreti, 1634, lib. vi, p. 263. Vid. Also Giulio Cesare Capaccio, Delle imprese, trattato di Giulio Cesare Capaccio in tre libri diviso. Nel primo, del modo di far l'Impresa da qualsevoglia oggetto, o Naturale o Artificioso con nuove manier si ragiona. Nel secondo, tutti ieroglifici, simboli, e cose Mistiche in lettere Sacre, o Profane si scuoprono; e come da quegli cavar si ponno l'Imprese. Nel terzo, nel figurar degli emblemi di molte cose naturali per l'Imprese si tratta, Appresso Gio. Giacomo Carlino \& Antonio Pace, Napoli, 1592, I, cap. VII, p. 18.

33. Publio Ovidio: Las Metamorfosis, unam, México, 1979, pp. 545-565.

34. Tertulian: De Corona Militis, in Migne, P. L. II, p. 85.

35. Jean Chevalier: Diccionario de los Símbolos, Herder, Barcelona, 2000, p. 630. 
bestowed to those generals returning undefeated to Rome and was assimilated by the emperors in Caesar's time, they would enter the city with a crown of laurel and waving a branch of the same plant in their hand. ${ }^{36}$

\section{Marie Josèphe Rose Tascher de Pagerie and her path to the THRONE}

Marie Josèphe Rose Tascher de Pagerie, eldest daughter of Joseph Tascher La Pagerie, lived the first 15 years of her life on the island of Martinique. In 1779 she married the rich young army officer Alexandre, Viscounte of Beauharnais, and moved to Paris. Although the Creole bore him two sons, Hortense (17831837) and Eugène (1781-1824), Alexandre was ashamed of her provincial manners; carelessness towards his wife became so manifest that in 1785 they signed for divorce. Joséphine remained in Paris ${ }^{37}$ for three years and returned to Martinique in 1788 . In 1790 a rebellion of slaves on the island forced her to return to Paris, where the Revolution was then in full process. Madame de Beauharnais frequented high society when she found herself involved in serious death threats the moment her husband fell ont of favor among leftist Jacobins and was guillotined in June 1794. The same Viscountess herself was imprisoned; but after the coup of 9 Thermidor (July 27) the terror ended and she was released. ${ }^{38}$ Joséphine married Napoleon and after a civil ceremony on March 9, 1796, Madame Bonaparte proved an indifferent woman who did not use to answer the passionate letters written by the future emperor to whom she was unfaithful. The general, aware of his betrayal, threatened to divorce her but thanks to the intervention of Eugène and Hortense, the children of Joséphine, Napoleon eventually discarded the idea. ${ }^{39}$

At the arrival of the coronation, Madame Bonaparte and Napoleon were forced to perform a religious ceremony to bless their marriage, because the Pope refused to consecrate future emperors if they failed to meet this requirement. Thus, in the Royal Chapel of the Tuileries on the eve of the coronation and in discreet private celebration, the couple went to the altar for the first time. ${ }^{40}$

The marriages of the children of Joséphine - Hortense with Louis Bonaparte, and Eugène with Augusta Amalia Ludovica of Bavaria - seemed to consolidate her position; however, her eccentricity and, above all, her inability to give a child to Napoleon stiffened the marriage as he longed for an heir with whom he wanted to strengthen his position as emperor and perpetuate

36. Rafael García Mahiques: Flora emblemática: aproximación descriptiva del código icónico, [tesis doctoral, Universitat de València, 1991], p. 373.

37. Jean-Claude Fauveau: Joséphine, l'impératrice créole: l'esclavage aux Antilles et la traite pendant la révolution Française, Harmattan, Paris, 2010, p. 153.

38. Frédéric Masson: Joséphine de Beauharnais, 1763-1796, Albin Michel, Paris, 1925, p. 226.

39. Jean-Charles Volkmann: La généalogie des Bonaparte, Éditions Jean-Paul Gisserot, Paris, 2001, p. 8.

40. Dimitri Sorokine: Épisodes et récits du Premier Empire, F. Nathan, Paris, 1967, p. 73. 
the government. Hoping to establish a politically convenient link to MarieLouise, daughter of Emperor Francis I of Austria, and with the aim of having a successor, the Corsican ordered the annulment of his marriage to Joséphine in January $1810 .^{41}$

The once Empress of France retired to her private residence in Malmaison and died on May 29, 1814, shortly after the abdication of Bonaparte. ${ }^{42}$

\section{The MAKING of AN IMPERIAL ICONOGRAPHy: LE SACRE DE L'EMPEREUR NAPOLÉON. JEAN-BAPTISTE ISABEY}

Strongly attached to the world of images, Napoleon wanted to keep a memory of the coronation ceremony as a work framed in the tradition of the book of Lewis' XV. Le Livre du sacre of Louis XV (1722) provides a detailed description of the event and its participants: Le sacre of SM l'Empereur Napoléon dans l'église métropolitaine de Paris. The painter Jean-Baptiste Isabey (1767-1855), a painter of portraits and a miniaturist, was commissioned to design the portraits and figures of costumes and uniforms, as well as seven historic paintings: La sortie de l'Empereur du palais des Tuileries; L'arrivée à l'Empereur Notre-Dame; Les Onctions; Le couronnement de l'Empereur; Les Offrandes; La prestation de serment de l'Empereur and La distribution des Aigles au Champ-de-Mars. ${ }^{43}$ Isabey's drawings created for Le Sacre de l'Empereur Napoléon would be elementary to build the corpus of images that would accompany Bonaparte and his wife in all subsequent performances. The book became the source of inspiration for great artists such as David Le Sacre (1805-1807, Paris, Musée du Louvre) - an artwork which would be unimaginable without Le couronnement de l'Empereur by Isabey. These works would mark the iconography of the imperial marriage where the empress was treated with great care in developing the various events of the ceremony and its visual representations within the book.

Regarding the attire for the ceremony, two types of garments were scheduled for Joséphine: the Grand habillement for the ceremony at Notre Dame, and the Petit habillement for other times during the day. ${ }^{44}$ Like the emperor, the empress initially wears the Petit habillement before leaving the ceremony and gets changed upon arrival at the palace of the archbishop to wear the Grand habillement. ${ }^{45}$ In a part of the description of the Grand habillement it was described in detail: «A manteau de velours pourpre, semé d'abeilles d'or

41. Mathieu-Mathurin Tabaraud: Du divorce de Napoleon Buonaparte avec Joséphine, veuve Beauharnais, et de son mariage avec Marie-Louise, archiduchesse d'Autriche, Egron, Paris, 1815, p. 5.

42. Françoise de Bernardy: Eugène de Beauharnais (1781-1824), Librairie académique Perrin, Paris, 1973, p. 464.

43. JeAn Tulard, Le Sacre de l'empereur Napoléon, 69.

44. «Dossier de presse pour l'Exposition temporaire du Musée du Luxembourg, Joséphine», of the website http://www.grandpalais.fr/ [Consulted on 13-12-2014], Paris, p. 12.

45. Ibidem, 22. 
dans la broderie sont enlacées des branches de laurier, chêne et d'olivier, qui la lettre entourent $\mathrm{N} »{ }^{46}$ Indeed, in the image Joséphine wears a long dress of white satin embroidered with golden bees to the bottom, embroidered and embellished with gold fringes and festoons, the bodice and sleeves are enriched with diamonds and covered with a mantle of purple velvet, splattered with golden bees embroidered and interwoven with branches of laurel, olive and oak, while surrounding the initial $\mathrm{N}$.

The image shows an entire framework in which the symbols of the emperor are included. Arranged within the decorated borders based on small bees and medallions with classical figures associated with philosophers and wise men in a thoughtful attitude, the representation is guarded at the bottom and top by the imperial eagle. The lower bird is perched on a round egg-and-darts frame containing the image of the Coronation of the Empress Joséphine while kneeling before Napoleon as she receives the crown. The eagle spreads its wings to two cornucopias symbolizing the abundance that involves the assumption of this new empire and is flanked by two allegories dressed in the classic way being given by each putti a bunch of cereal and a set of arrows, allegory of food and the defense of the people. On the frame, a laureate medallion shows the crown of Charlemagne and in the upper edge of the frame another eagle covered with the imperial cape lined with ermine and laureate and wearing the crown of the Carolingian emperor is shown.

Regarding the specification of Joséphine's Petit habillement appeared: «Le manteau de cour in velours de couleur avec une broderie de dix puces of hauteur, attaché à deux par ceinture agrafes; la roche de satin blanc, et semée brodée d'abeilles d'or. $\rangle^{47}$ In this image, the Empress wears again the mantle of crimson velvet embroidered with a set of two staples; the dress is again white satin embroidered and splattered with golden bees, with short sleeves and trimmed in feather-like shapes with diamonds. As in the previous picture, the rims of the frames have plenty of emblems and symbols of Napoleon. Disposed within a frame with candelieri decorations and effigies, the representation is also guarded at the bottom and top by the imperial eagle. The lower bird is flanked by characters dressed in classical Roman style with festive attitude while the upper repeats the previous pattern with a Laureate Medallion under the imperial cape and wearing the crown of Charlemagne. On the frame of the lower edge and closing the representation, the scene of La prestation de serment de l'Empereur is shown.

The whole display around Madame Bonaparte described both in the historical scenes as well as in the figures with the design of their attire matches perfectly the creation of Joséphine's imperial iconography.

46. Jean Tulard, Le Sacre de l'empereur Napoléon, p. 106.

47. Ibidem, 108 


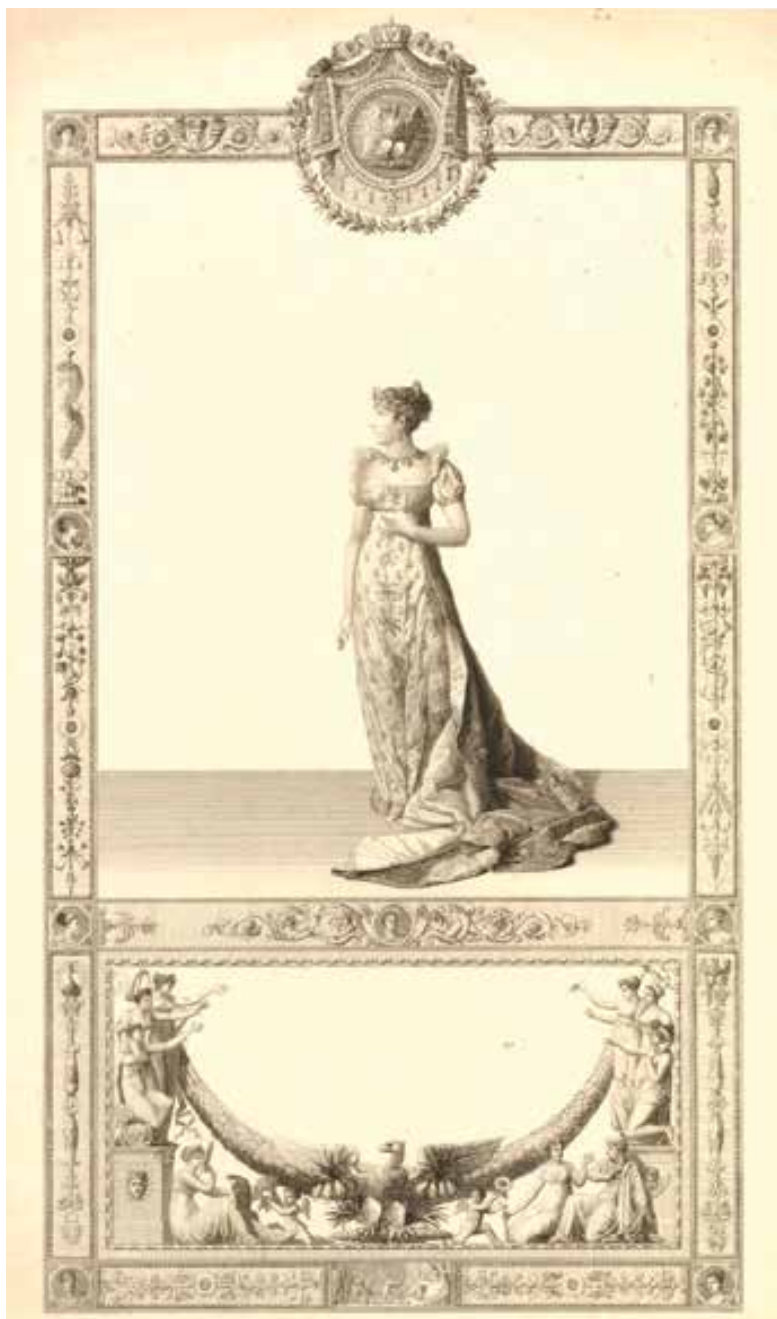

Fig. 1. Jean-Baptiste Isabey, Le Sacre de l'empereur Napoléon. Joséphine en Petit habillement, 1805, Musée du Louvre, Paris

4. THE SHADOW OF NAPOLEON IMPERIAL SYMbOLS IN PORTRAITS OF JOSÉPHINE

The presence of the emperor is evident in a series of portraits of the Empress. By means of key symbolic elements mentioned in the first part of this article, Napoleon marks the representations of his wife in order to consolidate her royal dignity and to legitimize her ascent to the throne being his consort. 
As previously noted, the portraits of the widow of Beauharnais were, until 1801, remarkably discreet: the work of 1798, Joséphine Bonaparte by JeanBaptiste Isabey, and The portrait of Joséphine de Beauharnais of 1800 by Pierre Paul Prud'hon (1758-1823) are good examples for that. They mainly consisted of images in which Madame Bonaparte was represented as a woman of a circumspect appearance and calm expression with a half smile, wearing simple outfits, free of ornamentation. Therefore her iconography was established with greater explicitness during the period when she held the title of Empress. Like her husband, Joséphine need an official image which made its way among the visual corpus of the people, in the same way the consort queens of the Bourbons had done previously. The decision to initiate this propagandist setup responded to the need to build a profile that irradiated hes royal figure on the French citizens demonstrating hes kindness and thereby endorsing her position on the imperial throne. Just as the Bourbons had the best court artists - Hyacinthe Rigaud, François-Hubert Drouais, Elisabeth Vigee Le Brunthose who were set to create a model of representation of the lady were Pierre Prud'hon, Antoine Gros, ${ }^{48}$ François Gérard (1770 -1837) and Jean-Baptiste Isabey.

Prud'hon, favorite painter of the imperial family and a teacher of drawing for the Empress, reflected in his portraits the principles of neoclassical portrait and landscape in the English way, creating an atmosphere of romantic melancholy. On the other hand, former favorite pupil of David, Antoine Gros, developed an expression from 1804 on for which he chose a formula which placed the values of family privacy before those of the imperial side with rigorous and dynamic compositions. ${ }^{49}$

The third major artist was François Gérard, whose portraits of Joséphine represented a new kind of effigy with a remarkable absence of official pomp, building an atmosphere of emotional and introspective poetry. Plenty of pictures of the Empress with the garments of the coronation ceremony were available at that moment. An example is the picture Joséphine's Coronation Day (Jean-Baptiste Isabey, 1804); in it, Madame Bonaparte is sitting on the imperial throne, dressed in ceremonial attire. The footprint of Napoleon can be seen in a display of imperial robes where a white satin dress shows the golden embroidered bees, an emblem of Bonaparte, Joséphine's curly hair combed in a bum, like under the kingdom of Louis XIV, in an allusion to the Old Regime they wanted to abandon but whose image of the power they intended to emulate. Among this sort of portraits of characters in imperial robes, it is worth mentioning Empress Joséphine (Henri-François Riesener, 1806, Châteaux de Malmaison et Bois-Préau, Malmaison France) where Riesener (1767-1828) shows Joséphine exhibiting a magnificent set of sapphires and

48. Carta d'Antoine Jean Gros à sa mère, Milán, 20 nivôse an V, París, foundation Custodia.

49. Amaury LefÉbure (ed.): Catalogue d'exposition: Joséphine, RMN - Grand Palais, Paris, 2014, p. 157. 
in which he highlights the presence of the Napoleonic emblem - the bees - in the embroidery of the coat as well as on the carpet covering the floor, and in the crown looming just behind the tiara on Madame Bonaparte's forehead. By the same token and as a good example of Grand habillement stands out Portrait of the Empress Joséphine with the coronation dress (the Gobelins factory taken from a painting by François Gérard, c. 1808-1810, Musée National du Château de Malmaison). In the same year Napoleon commissioned a replica addressed to another that become a tapestry on which eight Gobelin tapestry weavers worked. ${ }^{50}$ In this representation of the Grand habillement honey bees, intertwined branches of laurel, the letter N.- all of them imperial symbols and the crown placed on a blue cushion can be seen. The represented armchair is the throne of Fontainebleau Palace, installed in 1808, although originally planned for Saint Cloud. ${ }^{51}$ With very small variations in the display of symbols, in Joséphine de Beauharnais (Étienne Lethière Guillon, 1807, Musée National du Château) the armrests show two orbs in which on the surface the initial $\mathrm{N}$ of Napoleon is engraved, flanked by two stars, and thereby the sun king is again seconding the ceremony.

Next in chronological order there is Empress Joséphine (Robert Lefèvre, 1805, Napoleonic Museum). In this picture, Joséphine is portrayed standing, wearing an exquisite dress and a red coat over which bees, embroidered in gold, fly. Well known are two half bust portraits of Joséphine made by Lefèvre (1755-1830), which repeat the same iconography in Malmaison. ${ }^{52}$

Following the example of the emperor, members of the imperial family liked to see their sculptured effigies represented and we should indicate that in the empire all rooms had their relevant bust or statue. Firmly established in France, the tradition of portraits was represented by sculptors such as JeanAntoine Houdon (1741-Paris), Joseph Chinard (1756-1813) and François Joseph Bosio (1769-1845). Between 1806 and 1808, Chinard himself would create Bust of Empress Joséphine (Joseph Chinard, c. 1806-1808, Châteaux de Malmaison et Bois-Préau, Malmaison France), sculpted in Milan during her stay in that city as a companion of Napoleon for his coronation as King of Italy. The work shows a solemn portrait of Joséphine clad in a dress with scalloped shoulders and marked by neoclassical idealization. Madame Bonaparte smiles and slightly turns left showing her sophisticated braided hair that is held back with on outstanding diadem with branches in the shape of ears of wheat and dotted with daisies. The allusions to the imperial dignity are evident in the eagle with outstretched wings and bees, while present, are kept at a discrete level.

50. Ibidem, 93.

51. «Dossier de presse pour l'Exposition temporaire du Musée du Luxembourg, Joséphine», of the website http://www.grandpalais.fr/ [Consulted on 13-12-2014], Paris, p. 11

52. Giulia Gorgone (ed.): Museo napoleonico, Electa, Roma, 2008, p. 23. 


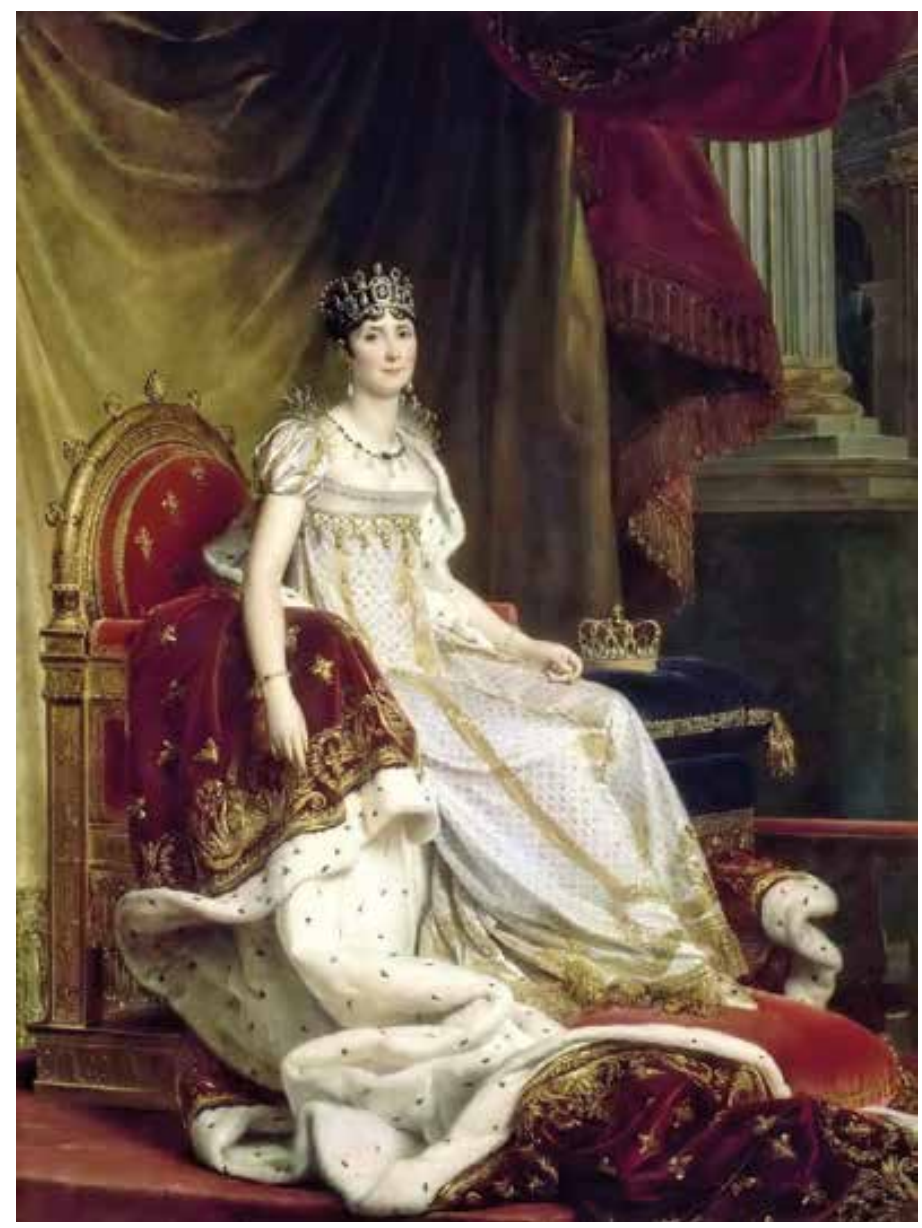

Fig. 2. Manufacture des Gobelines d'Après François Gérard, c. Portrait en pied de l'impératrice Joséphine dans le costume du couronement 1808-1810, Musée National du Château de Fontainebleau, Fontainebleau

Another portrait typology is that in which Joséphine is shown alone but partnering with the emperor, as occurs in Miniature representing Napoleon and Joséphine (Baraton Pierre and Jean François Soiron. C. 1807, Louvre). The cover of the tobacco box, framed by a carved decoration of laurel branches and jewelry, merges the portraits of the imperial marriage. Napoleon wears a green uniform of Colonel of the Grenadier Guards and shows the insignia «grande étoile de grand aigle d'or» of the Legion of Honor, ${ }^{53}$ with the inscription

53. Anne de Chefdebien; Laurence Wodey: Ordres et décorations en France, Musée national de la Légion d'honneur et des ordres de chevalerie, Belgique, 2006, p. 56. 


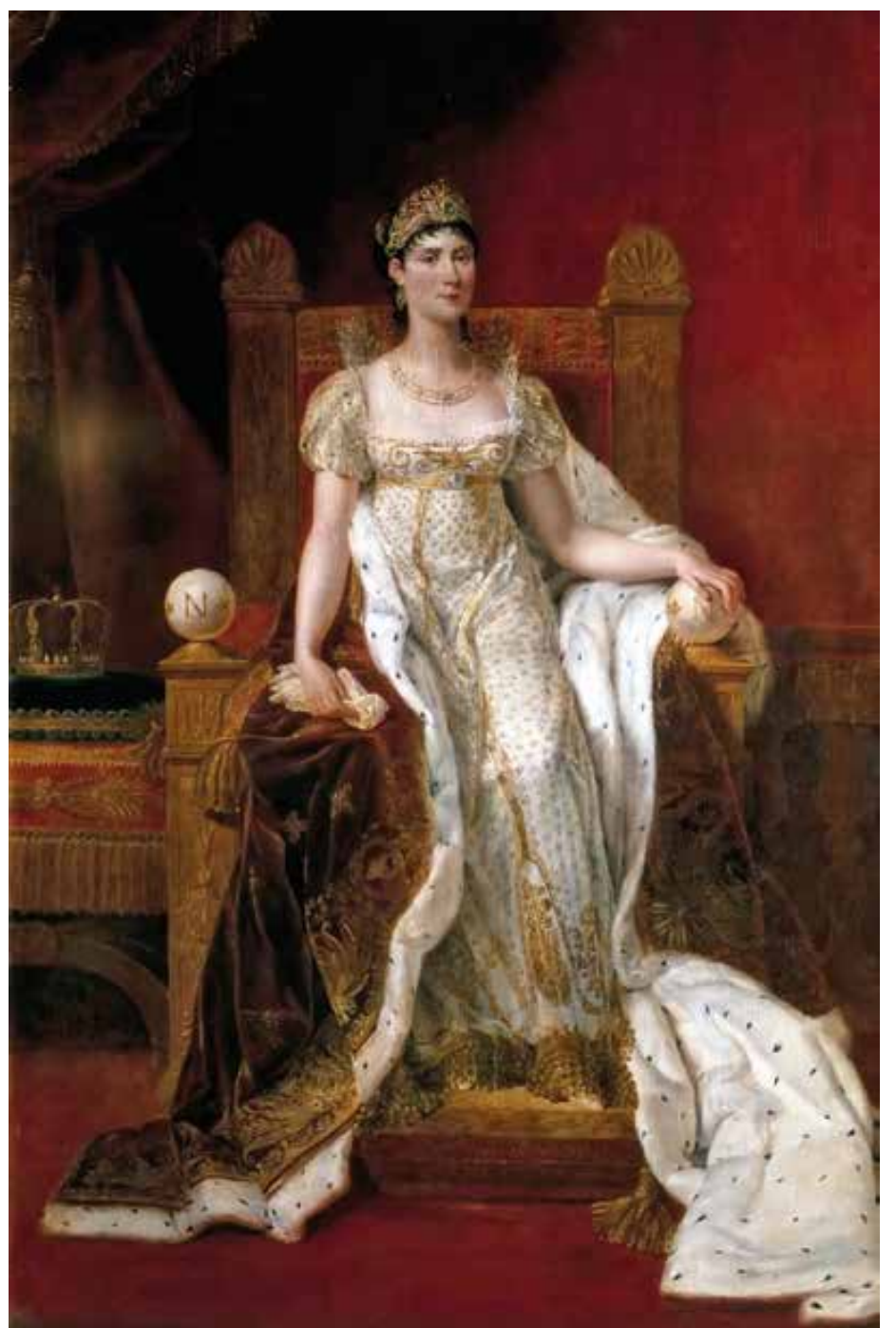

Fig. 3. ÉTIENNE Guillon LethiÈre, Joséphine de Beauharnais 1807, Musée National du Château, Versailles

Napoleon Emp. Des Français, and on the back: Honneur et Patrie, ${ }^{54}$ and the plate of grand aigle of the Legion of Honor. ${ }^{55}$ Likewise, Joséphine wears a

54. Lesja VAndensane (ed.): Pour l'Honneur et pour la Gloire. Napoléon et les joyaux de l'Empire, Fonds Mercator, Bruxelles, 2010, p. 66.

55. Anne de Chefdebien; Laurence Wodey, Ordres et décorations, p. 54. 


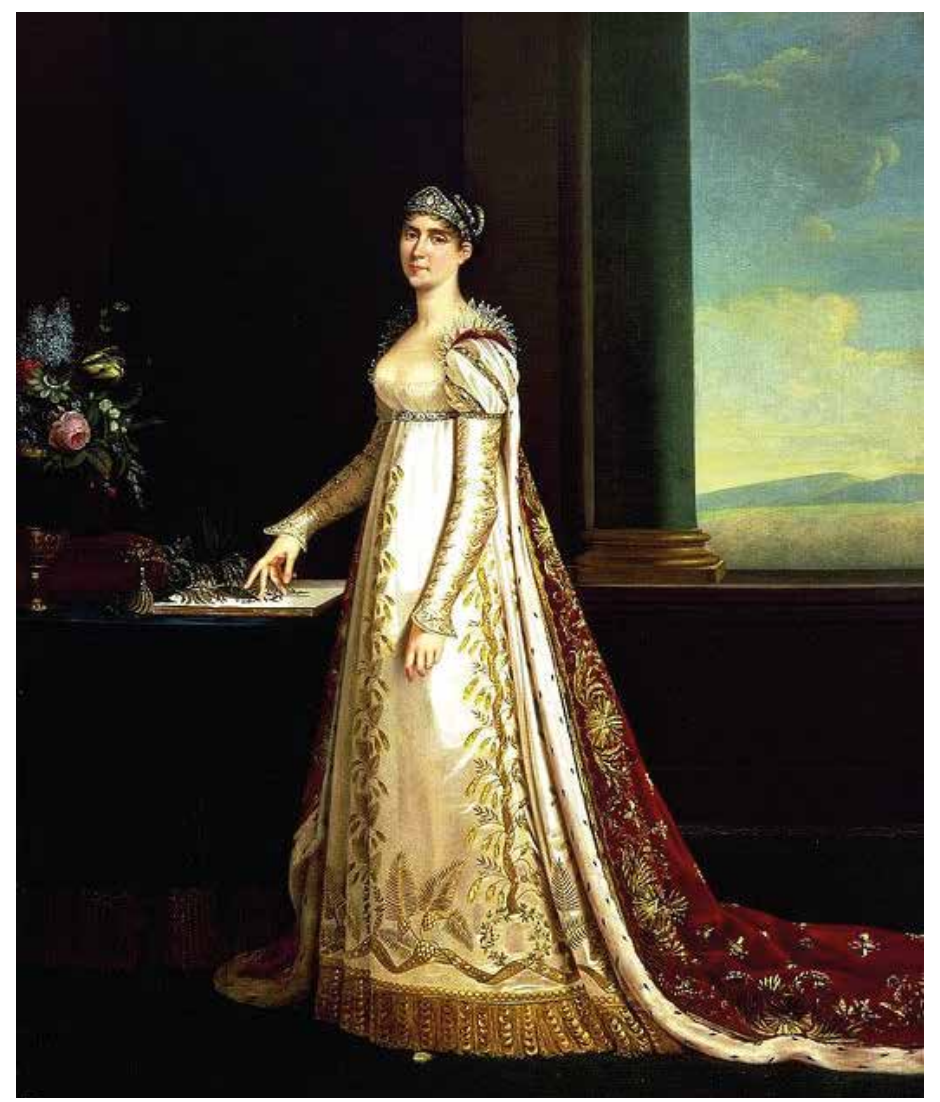

Fig. 4. Robert LeFÈVRE, L'impératrice Joséphine 1805, Malmaison et Musée de Picardie, Amiens

dress with on embroidered collar in Cheruscan style, an ermine coat and a set of jewelry made of pearls. ${ }^{56}$ Jean François Soiron (1756-1812) implemented several portraits of the imperial couple, one of which was presented at the Salon of 1808. It was a portrait dated 1807 , belonging to the Wicander collection, preserved in the National Museum in Stockholm which was inspired by miniatures made by Jean-Baptiste Isabey (Portrait of Napoleon Foundation of Napoleon and Joséphine portrait, Musée du Louvre, Arts graphiques). ${ }^{57}$ In it, the Empress not only exhibits the imperial robe and eagle with his wings spread which are symbolizing the rule of her sponse but she also partners with a portrait of himself.

56. Amaury Lefébure (ed.), Catalogue d'exposition, p. 97.

57. Ibidem, 97. 


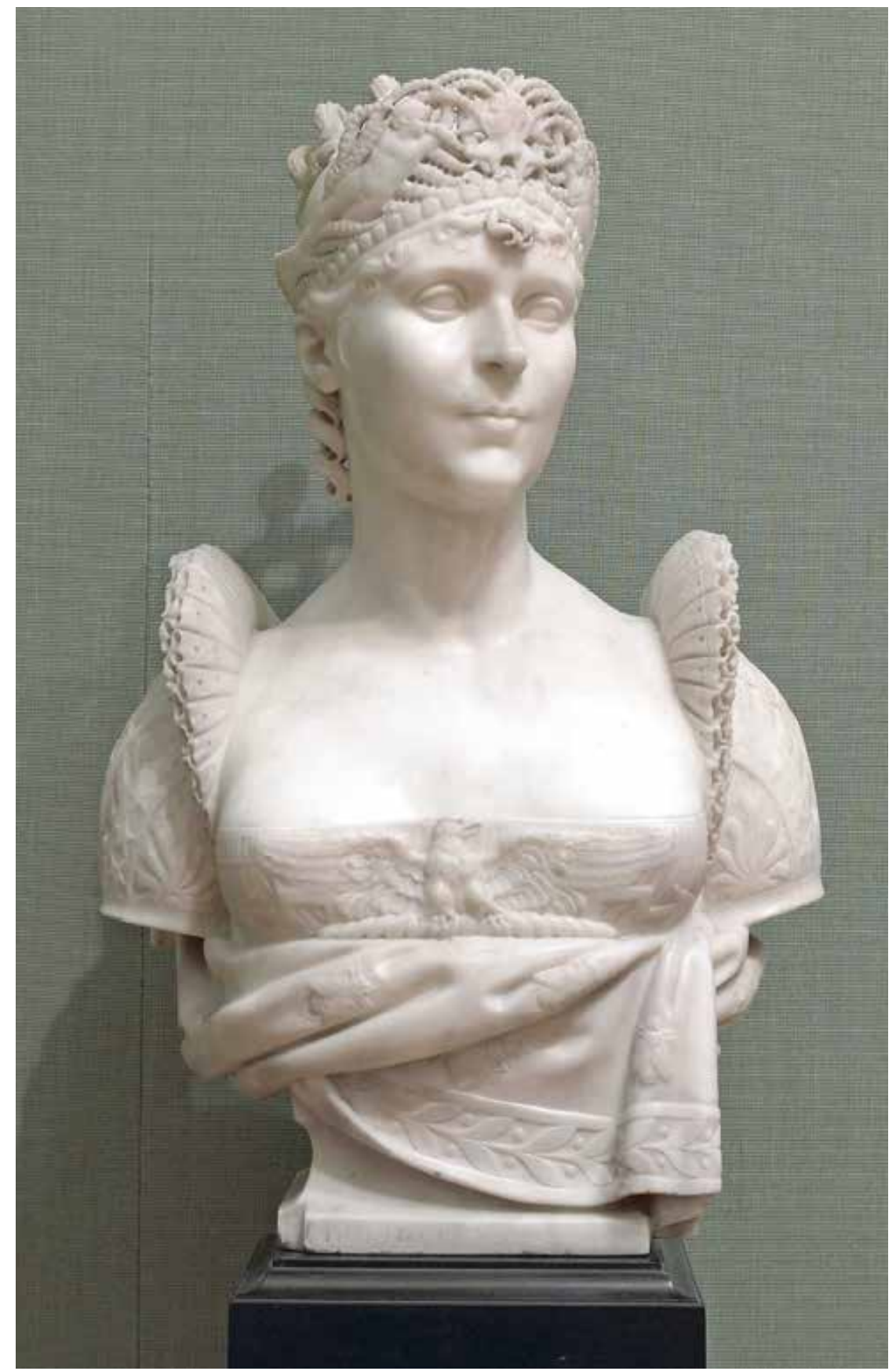

Fig. 5. Joseph ChinARD, L'impératrice Joséphine 1805, National Gallery Canada, Ottawa 


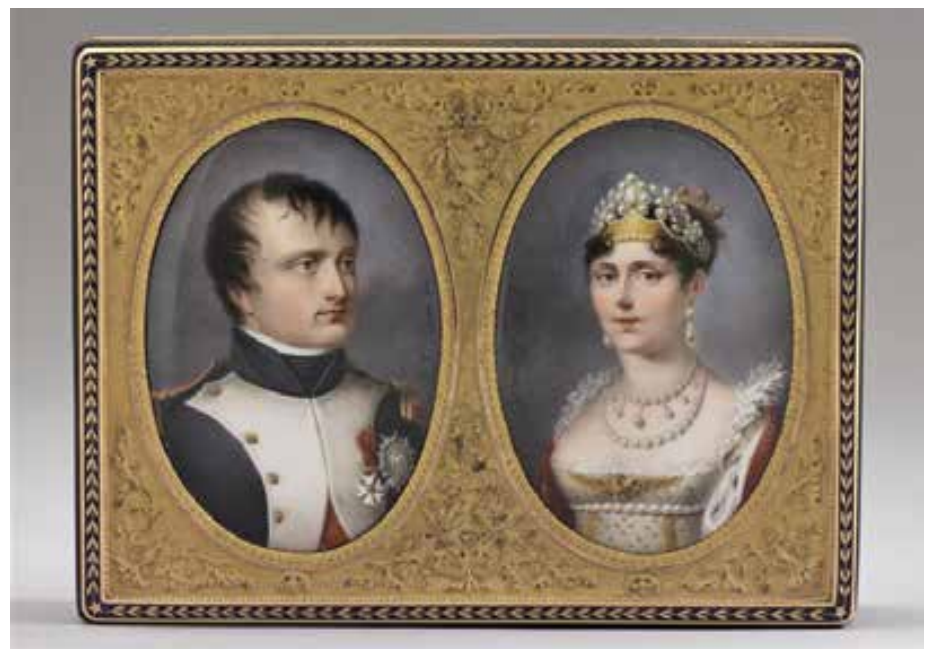

Fig. 6. Pierre Baraton y Jean François Soiron, Tabatière c. 1807, Louvre, Paris

Closer to the model of representation by herself and with the imperial presence expressed through symbols of power we have dealt with above, we must speak of Empress Joséphine (Ferdinand Paul Louis Quaglia; DIHL Christophe Erasimus, which is an expanded reproduction made at the Dihl et Guerhard factory in Paris, a miniature ivory by Quaglia, 1809-1814, Musée Jacquemart-André). Joséphine appears in straight profile with her head turned towards the viewer, wearing a white muslin dress with lace and behind her right hand, the trace of Napoleon which consists of a crown on red velvet shown as a green curtain opens, thereby adding drama to the whole scene. On the left, a column reads «Joséphine, Empress». 58

\section{Side By Side With NAPOlEON: THE PORTRAit in THE PORTRAit}

Of all the portraits of the empress with Napoleon where he is represented by the imperial symbols, we would like to highlight those in which the emperor becomes much more evident by his inclusion in the work that represents his wife. However, before taking a more in-depth look into the Joséphine case we should ask what the visual tradition was that led to a revival of the portrait in the portrait and the miniature during the Napoleonic empire.

58. Chiara Parisio: Ferdinando Quaglia, 1780-1853, da Piacenza a Parigi, Starrylink Editrice, Brescia, 2012, p. 27; Alain Pougetoux: «Paul-Ferdinand-Louis Quagila, portrait de l'impératrice Joséphine», Société des amis de Malmaison Bulletin, n 39, 2005, p. 49. 
As we have already seen, the emperor built bridges to classical antiquity to the point of resuming the habit of erecting statues of himself in public places, a practice inherited from the Roman Republic. The truth is that this tradition was not recovered by Bonaparte, who only followed the old custom of publishing the ruling image through sculptures, which originated in classical times, and assimilated by many other leaders who preceded him. ${ }^{59}$ The tradition of an official portrait was initiated in time of Augustus, 23 BC. This model fully combined the princeps, or governor, and the state, in such a way that the emperor could project into the Roman people his magnanimous imperial dignity and power. ${ }^{60}$ That is the reason why Napoleon wanted his face reflected in coins, busts, sculptures, miniatures, prints, etc.

In the advent of the Renaissance, the portrait arose as one of the major artistic genres ${ }^{61}$ adjusted to specific codes, ${ }^{62}$ something particularly noticeable in the absolutist courts. ${ }^{63}$ While it is true that during its inception in court environments its use was relegated to intimate spaces of sentimental or devotional character, ${ }^{64}$ it is also true that it soon would be used to expand the figure of the leader in the public domain. ${ }^{65}$

However, what we must highlight is the "portrait in the portrait»; a visual exercise in which the effigy located within a portrait invited to establish a connection between the viewer and the figures represented and the bond between them. In the Spanish court of the sixteenth century they «generally take the form of small effigies of kings that accompany and characterize some characters. These are cases in which a personality intrudes on another, and witness a vital dependency». ${ }^{66}$ This typology of portrait ${ }^{67}$ can take two forms, either in the presence of the second actor through a sculpture or a painting, or by means of portable thumbnails. ${ }^{68}$

As Javier Portús points out, although there is a family relationship with the monarch represented, that is not to be interpreted on an emotional level as the nuances between members of a royal family of the Modern Age go far beyond,

59. See Paul Zanker: Augustus und die Macht der Bilder, C.H. Beck, München, 1987.

60. See Stefano Ferrari: La psicologia del ritratto nell'arte e nella letteratura, Laterza, Bari-Roma, 1998; Bianca Maria Felletti Maj: «Iconografia romana imperiale da Severo Alessandro a M. Aurelio Carino (222-285 d. C.)», Quaderni e guide di archeologia, n. ${ }^{\circ}$ 2, 1958; RANUCCIO BiAnCHI BANDinelLi, Il problema del ritratto, in L'arte classica, Editori Riuniti, Rome, 1984.

61. See John Pope-Hennessey: El retrato en el Renacimiento (1964), Akal, Madrid, 1985; Lorne CAmpbell, Renaissance Portraits, Yale University Press, New Haven and London, 1990.

62. See ÈduARd Pommier: Theories du portrait de la Renaissance aux Lumières, Gallimard, París, 1998.

63. See Mariana Jenkins: Il ritratto di stato, Istituto della Enciclopedia Italiana, Roma, 1977.

64. See el estudio de Јасов BuRCKнаRDт: Il ritratto nella pittura italiana del Rinascimento (1898), Bulzoni, Roma, 1993.

65. JAvier Portús: «Soy tu hechura. Un ensayo sobre las fronteras del retrato cortesano en España». En: F. Checa Cremades; J. Portús; M. Falomir Faus (eds.), Carlos V: retratos de familia, 2000, Sociedad Estatal para la Conmemoración de los Centenarios de Felipe II y Carlos V, Madrid, pp. 181-182; GaliannE y Pierre Francasterl: El retrato, Cátedra, Madrid, 1987.

66. Ibidem, pp. 182-191.

67. Julián Gállego: El cuadro dentro del cuadro, Cátedra, Madrid, 1978, pp. 73-86.

68. JAvier Portús, «Soy tu hechura», p. 191. 
also implying links of subjugation. So when we see a medallion bearing the portrait of Napoleon within portraits of Joséphine, it may not bear a romantic significance of the moment but, like the Habsburgs, «a sign of belonging to a lineage that recognizes as a leader the most powerful lord in Europe». ${ }^{69}$

Obviously this tradition was maintained until the dawn of modern times and a revival of miniature portraits can be observed during the First Empire. Napoleon, using artistic and luxury resources to suit their propaganda purposes, ordered a fast, steady pace of manufacturing of these small portraits in order to be given as presents for European states. ${ }^{70}$

The objects decorated with miniatures contained, as in the previous century, some hair belonging to a beloved one. Miniatures, made by painters such as Jean-Baptiste Isabey, Jean Urbain Guérin (1760-1836) and JeanBaptiste Augustin (1759-1832) were painted, surrounded by pearls, diamonds and other stones pleated in the center of bracelets of pearls mounted on waves or medallions hanging around necks. ${ }^{71}$ Objects that, among the effigies we will later deal with, show the face of the Emperor Bonaparte.

We begin this review with one of the most isolated portraits of the rest of the production concerning the representation system of Joséphine: Joséphine Bonaparte First Consul's wife (Andrea Appiani, c 1801, private collection). This portrait was painted at the same time as the portrait of Napoleon Bonaparte (Andrea Appiani, c. 1801, private collection, Montreal, Canada). With an austere decor inside a palace, Joséphine, clad in a rich dress decorated with beads, is wrapped in a coat, designed in the style of a toga and hiding much of what is sensed as a luxury dress, reminiscent of a heroine of the classic drama. The jewelry she is wearing emphasizes references to Italy, hence referring to the most recent events: we can see three cameos in her necklace, a reproduction of three medals which were found around 1797 and representing the labors of Hercules in the middle of golden medallions with rubies and pearls. ${ }^{72}$ From left to right, commemorative medals in allegorically representing the battle of Millesimo, the passage of Tagliamento and the Battle of Castiglione, subjects that the painter resumed later in the decoration of the Royal Palace of Milan. Several contemporaries testified that Joséphine had a passion for cameos and that her desire was to acquire these objects during her stay in Italy. Here the artist subtly transforms what could be only the manifestation of a passing fashion and what the real Joséphine is: little more than an arbiter of fashion, the wife of a statesman. ${ }^{73}$ The Milanese painter portrays Joséphine with the look of a Roman matron. Appiani (1754-1817) presents her as a vivacious

69. «On the other hand, we must point out that the presence of miniature portraits within other portraits has mainly been documented in connection with aulic contexts». Ibidem, p. 191.

70. Eloy Martínez Lanzas: La miniatura. Época imperio (1804-1814), on the website Colección Martínez Lanzas-de las Heras [Consulted on 18-1-2015].

71. Lesja Vandensane (ed.), Pour l'Honneur, p. 163.

72. Ibidem, p. 159

73. Amaury Lefébure (ed.), Catalogue d'exposition, p. 75. 


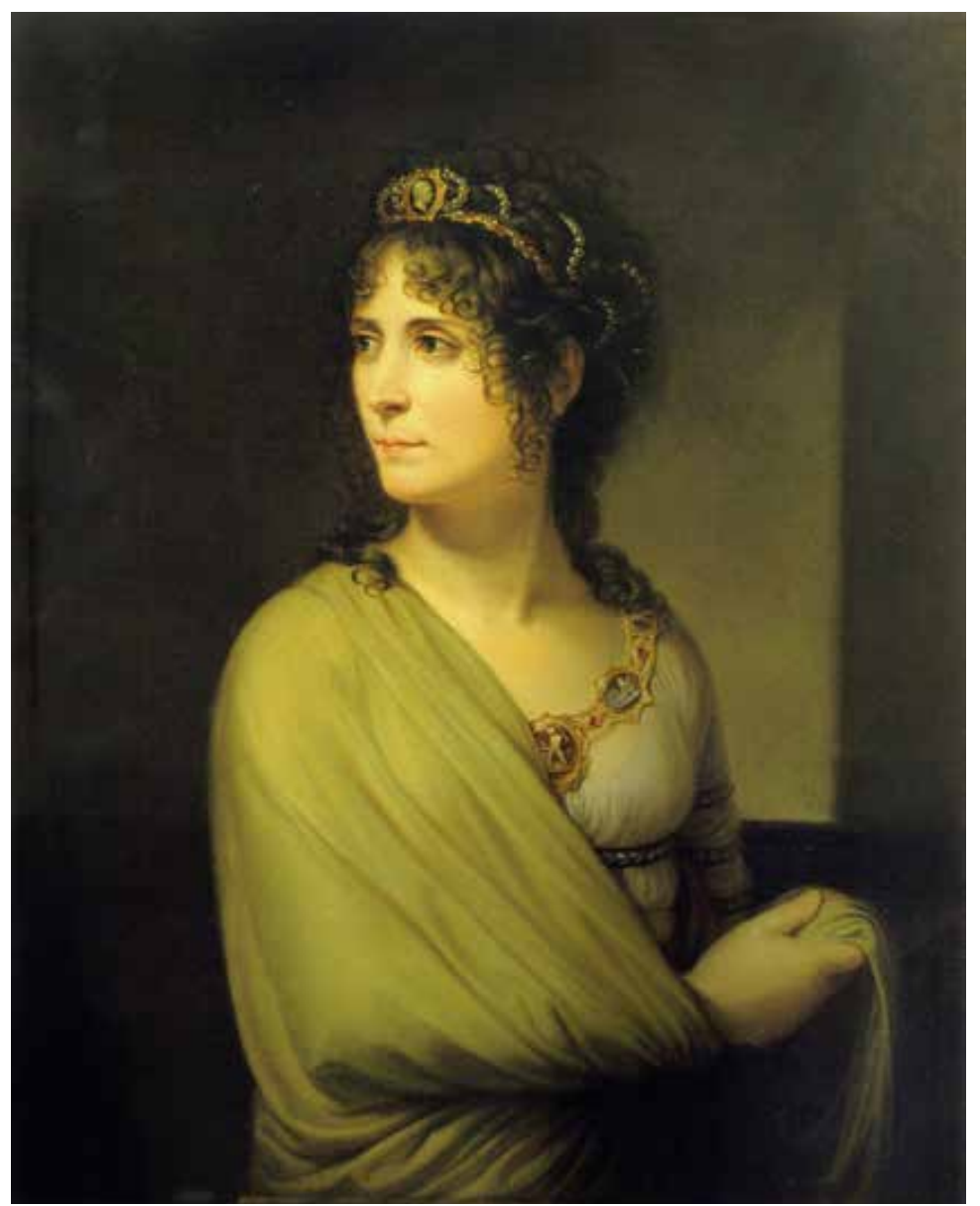

Fig. 7. Andrea ApPiani, Joséphine Bonaparte épouse du Premier consul c. 1801, private collection, Belgium

seductress, emphasizing her beautiful features. Her loose hair of a natural color, in contrast with the powdered wigs in the Bourbon period, denotes a connotation of revolution transcending the simple environment of fashion and turning into the realm of thought that foreshadows a new historical period. The diadem in her brown hair is centered with a cameo which reproduces what looks like the profile of a Roman bust properly adapted to the physiognomy of Napoleon. ${ }^{74}$ Not only is the presence of the emperor remarkable in the cameo and in the display of a performance dedicated to the emulation of the classic

74. Eleanor P. DeLorme: Joséphine and the Arts of the Empire, J. Paul Getty Museum, Los Angeles, 2005, p. 23 
Roman past of which the general was so fond, but also in the mount on which the cameos settle themselves. These are designed in a star shape reminiscent of the sun and therefore one of the least recurring symbols in the corpus of imperial images but not for that matter nonexistent.

The jewels composed of cameos were a great political value in the eyes of the emperor. ${ }^{75}$ If Napoleon was impressed by the classic cameos, Joséphine, who set the tone in fashion, made them leave their traditional place in the cabinets of collectors to take them to the jeweller's shop. ${ }^{76}$ The beauty of these, either ancient or modern engraved stones, led to the creation of stylish outfits adorned with pearls, diamonds or classical motifs - greek keys, olive leaves, acanthus, myrtle and laurel, liras, vine, honeysuckle and canes. ${ }^{77}$

In another portrait, there is a particular case focused on Empress Joséphine in Strasbourg (Jean-Baptiste Ysabey, 1805), where Madame Bonaparte, crowned at the time as Empress consort, appears during her visit to Strasbourg in 1805 clad in traveling clothes composed of a coat of purple velvet, with a purple feather as only hair ornament on her dark hair which is pulled back, carrying in her hand a handwritten letter while turning to the right of the frame, and a jewel hanging from a chain on her chest. Following the tradition of miniatures evoking the loved one, whose image was hoisted, Isabey represented Joséphine in Strasbourg bearing the portrait of Napoleon. In it the emperor is wearing the statutory uniform of the French military, and it is hanging from a golden necklace as decoration to express the pride that inspired the success of her husband. ${ }^{78}$

The third of the works that shows a statue of the emperor in an image of Joséphine is a bust made by Chinard, Empress Joséphine (Joseph Chinard, 1805, National Gallery Canada). Like in a previous bust by the same artist, Madame Bonaparte is represented in profile, suggesting a barely perceptible but very elegant smile. Joséphine wears a crown and a tiara that simulates diamonds, which features a cameo of her husband Napoleon in profile on the cross of the Legion of Honor and supported by two putti. The main symbols of imperial power that adorn her dress and mantle are the star - an allusion to the Sun King - and the cane in the sleeves; the eagle with outspread wings holding a beam on his chest; and also olive leaves and simulated bees embroidered on the blanket tucked under his chest.

75. This is evidenced by the Imperial Decree 1808 , by which he appropriates forty five cameos and thirty-six intaglios belonging to the national collection held in the Cabinet des Médailles the Bibliothèque Nationale. Lesja Vandensane (ed.), Pour l'Honneur, p. 156.

76. Cameos and intaglios combined in a single jewel. Needles with cameos used to close shoulder dresses gowns inspired by antiquity, were particularly admired. Bernard Chevallier; Karine Huguenaud: Trésors of the Fondation, No. 53, p. 75 and No. 105, p. 125; Lesja VAndensane (ed.), Pour l'Honneur, p. 159.

77. Lesja Vandensane (ed.), Pour l'Honneur, p. 159.

78. Bernard Chevallier; Karine Huguenaud: Trésors, n. ${ }^{\circ}$ 147, p. 165; Lesja Vandensane (ed.), Pour l'Honneur, p. 163. 


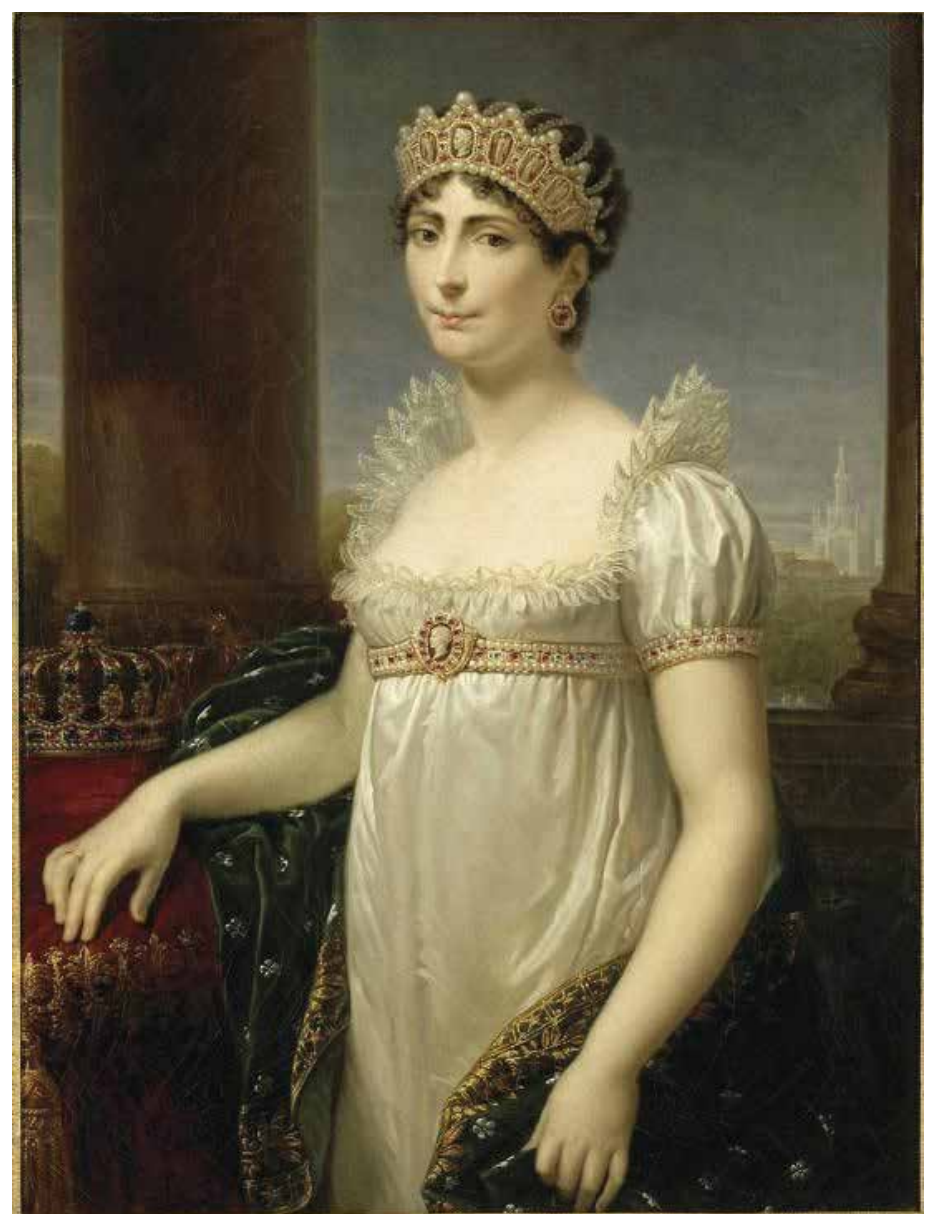

Fig. 8. ANDrea Appiani, Portrait de l'impératrice Joséphine, reine d'Italie 1807, Musée National des Châteaux de Malmaison et de Bois-Préau, Rueil-Malmaison

It is also worth noting the Portrait of the Empress Joséphine, Queen of Italy (Andrea Appiani, 1807, Musée national des châteaux de Malmaison et Bois-Préau). This canvas is next to Napoleon King of Italy, of which several examples are known (Vienna, Kunsthistorisches Museum, Dalmeny House, Écosse, Rosebery collection; Napoleonien Musée de lîle d'Aix). Joséphine wears a coat of green velvet embroidered with silver flowers, such color and metal were used for the royal ornaments in Italy; near her is the crown she wore in the coronation as the queen consort on May 26, 1805; in the distance, a view of the capital of the kingdom, Milan, can be seen with the silhouette of 
the cathedral,where the ceremony was held. In the center of her tiara, a cameo shows the laureate head of Emperor Napoleon flanked by ten symbolic figures of winged victories. Bonaparte's face appears again in the buckle of Joséphine's belt, but showing in this effigy a much younger appearance. ${ }^{79}$

Finally, we should not forget the miniature Joséphine (Pierre Louis Bouvier, 1812, Louvre). ${ }^{80}$ We will not go into the details of the attire of the empress who, indeed, exhibits the emblem of Bonaparte but we draw attention to the chair since Napoleon's laureate head appears on its side on a canvas inspired in Ingres' Napoleon crowned as Emperor (1806, Musée de l'Armée). Joséphine's position shifts slightly to reveal Napoleon's face and she slightly tilts her head so that the former can be noticed. This is the journey through the iconography of an empress who, accompanied in her portraits by her husband Napoleon and framed in a propagandistic display of the image of power, was forced to resign for the greater glory of the empire in whose imaginary she had already formed her own space.

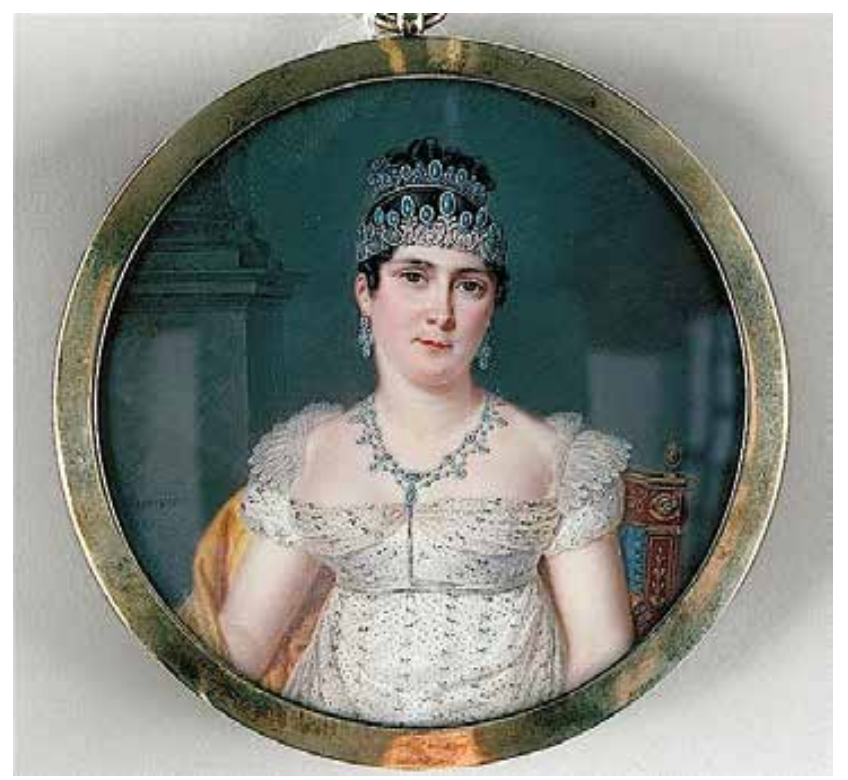

Fig. 9. Pierre Louis Bouvier, Joséphine 1812, Musée du Louvre, Paris

79. Lesja Vandensane (ed.), Pour l'Honneur, p. 159

80. Amaury Lefébure (ed.), Catalogue d'exposition, p. 179. 